\title{
Elevated CA15-3
}

National Cancer Institute

\section{Source}

National Cancer Institute. Elevated CA15-3. NCI Thesaurus. Code C81731.

A laboratory test result indicating the presence of an increased level of the tumorassociated antigen (TAA) CA15-3 in a blood or serum sample. 